Proc. Estonian Acad. Sci. Biol. Ecol., 2004, 53, 1, 52-67

\title{
Breeding bird communities in two Estonian forest landscapes: are managed areas lost for biodiversity conservation?
}

\begin{abstract}
Asko Lõhmus
Institute of Zoology and Hydrobiology, Centre of Basic and Applied Ecology, University of Tartu, Vanemuise 46, 51014 Tartu, Estonia; Asko.Lohmus@ut.ee

Received 4 September 2003, in revised form 31 October 2003

Abstract. To establish new reserves for biodiversity, the conservation value of currently managed forests should be assessed. I compared the bird fauna of a large reserve (Alam-Pedja) and an adjacent managed forest landscape in east-central Estonia. At 20-ha scale, managed forests had a denser and more species-rich bird fauna and as high abundance of species of conservation concern as the reserve. This was due to the higher small-scale diversity of vegetation types and a higher share of fresh-type forests in the managed area, since at the landscape scale, the species richness of the managed forest and the reserve were similar. Moreover, the species-area curves of the reserve and a combined sample of the reserve and the managed landscape did not differ, indicating that the latter added new species only due to enlarged area and not because of a distinct fauna. Thinnings changed community composition and tended to decrease species-richness. I conclude that managed forest landscapes are impoverished but still valuable for the conservation of forest birds in Estonia. Using the existing middle-aged or old unmanaged second-growth for new reserves seems to be an acceptable conservation strategy if the potential sites of conservation are immediately excluded from commercial use.
\end{abstract}

Key words: forest birds, line transect counts, managed forest, reserve, thinning.

\section{INTRODUCTION}

In northern Europe, including Estonia, an effective conservation of the biodiversity of old growth would require much larger areas under protection than currently (Virkkala, 1996; Angelstam \& Andersson, 2001; Lõhmus et al., 2004). In particular, new reserves should comprise those forest environments that are 
under-represented in protected areas nowadays, i.e. mostly productive types of silvicultural interest (e.g. Stokland, 1997; Lõhmus et al., 2004). Therefore, it is important to know whether the productive forests outside reserves have retained their value for biodiversity and how much they contribute to the existing reserves.

Unfortunately, there is no straightforward way to answer these questions. First, the lagged response of biota to habitat degradation means that a degraded landscape can keep a natural-like species richness for some time. Yet, much of the biota in such a landscape may form only a "species credit" - remnant populations, going extinct in the future if habitat quality does not improve for them (Hanski, 2000). Indeed, the extant primeval stands have still very high species richness and many rare and threatened species in Estonia (Trass et al., 1999; Vellak \& Paal, 1999; Parmasto, 2002), despite their less than 1\%-coverage of forest land outside reserves, which is well below the threshold of long-term survival of populations (Trass, 1997; Lõhmus, 2002; Andersson et al., 2003). Hence, a conservation assessment should cover the species pool in the whole landscape, not only in the conspicuous remnants of old growth. Such an analysis would be very timeconsuming, whereas the future of the "species credit" depends critically upon how quickly the landscapes will be restored for them (Hanski, 2000). Thus, for practical purposes, one could use some indicative and easily studied species group.

Secondly, differences in protected and managed environments may conceal management effects, unless the differences in vegetation types are also addressed (Thompson et al., 2003). Thirdly, since the survival of the "species credit" in managed landscapes depends largely on future developments, conservation assessment should cover also the prospects. Probably the cheapest and quickest way to have old growth in sufficient amounts in Estonia is to protect the relatively large, but declining, supply of old secondary forests (Lõhmus, 2002). While these forests would obviously lose their value as habitats for old growth species after clear-cutting, the effects of cuttings that retain tree cover (mostly thinnings) are not known. If these were also detrimental, all management should be stopped in areas likely to qualify as future reserves.

Birds are considered suitable taxa for conservation assessments in the Baltic forest landscapes (Angelstam et al., 2004). In this paper, I compare bird assemblages in a large reserve and an adjacent managed forest landscape. It was not possible to replicate the landscape-scale analysis because of technical constraints, but this is a common situation at large scales and its consequences depend on the particular problem (Oksanen, 2001). My case is confined to a previously well-studied area that represents the general Estonian situation well (Lõhmus, 2002). I ask whether the avian abundance, species richness, and occurrence of species of conservation concern differ between the managed and protected landscape, how the managed landscape adds to the species richness of the reserve, and what the effects of management on potential reserves are. To do this, I address the effects of different vegetation types on the bird variables and I also compare bird faunas in recently thinned and unthinned areas of some forest types. 


\section{MATERIAL AND METHODS}

Study area and sampling design

The study was carried out in a $900-\mathrm{km}^{2}$ area with random (UTM-grid) borders in east-central Estonia $\left(58^{\circ} 25^{\prime} \mathrm{N}, 26^{\circ} 20^{\prime} \mathrm{E}\right)$. Forest land covers $40 \%$, mires $8 \%$, flood-plains $7 \%$, rivers and lakes $2 \%$, and settlements $6 \%$, the remaining $37 \%$ being mostly open agricultural landscape. Fifty percent of the forests grow on wet soils. Because of a long clear-cutting history, most forests have one even-aged tree layer, consisting on average of $46 \%$ birch (Betula spp.), $17 \%$ Scots pine (Pinus sylvestris), 15\% Norway spruce (Picea abies), 9\% aspen (Populus tremula), 7\% grey alder (Alnus incana), 6\% black alder (A. glutinosa), and 1\% other tree species. The area includes different production forests (four state forest districts as well as forests belonging to a large number of private owners) and $15 \%$ of the territory (23\% of the forest land) is covered by the Alam-Pedja Nature Reserve. The landscape composition is very similar to the Estonian average, although the forests contain more birch and fewer coniferous trees (see Lõhmus, 2002, 2003b for details and a map).

As a part of a general study on forest structure and biota, 30 straight northsouth transects (20 in managed forests, 10 in the Alam-Pedja Nature Reserve) were randomly established on forest land (forest and clear-cuts). More transects were established in managed forests to better represent their larger area and to include more recently managed (thinned) forests for comparison with unthinned stands; this sample size difference was addressed in the analysis stage. Each transect started from a randomly selected point and crossed openings to continue from their other side. Initially, each transect was $2 \mathrm{~km}$ long but in the field (particularly in mires), some parts were reclassified as non-forest land due to their less than $30 \%$ canopy closure (the official criterion for forest definition in Estonia). The actual average length of transects was 1955 (range 1760-2010) $\mathrm{m}$ in managed areas and 1820 (range 1340-2000) $\mathrm{m}$ in the reserve. Ten main vegetation types were distinguished on the transects (Table 1).

\section{Fieldwork}

The fieldwork was carried out by the author between 26 May and 13 June, in early mornings with favourable weather. To reduce effects of one year, a random half of transects both in managed forests and the reserve were studied in 2002, and the other half in 2003. In addition to bird counts, the borders and characteristics of habitat patches and their management status (whether or not recently thinned) were routinely determined. The principles of bird census followed the Finnish line transect method (Järvinen et al., 1991; a version for Estonian conditions Ellermaa, 2003), which is essentially a single-visit mapping and has been used in the Estonian forests also earlier (Rootsi et al., 1988). The observer distinguishes birds on a central (main) belt of the transect and outside it (supplementary belt). 


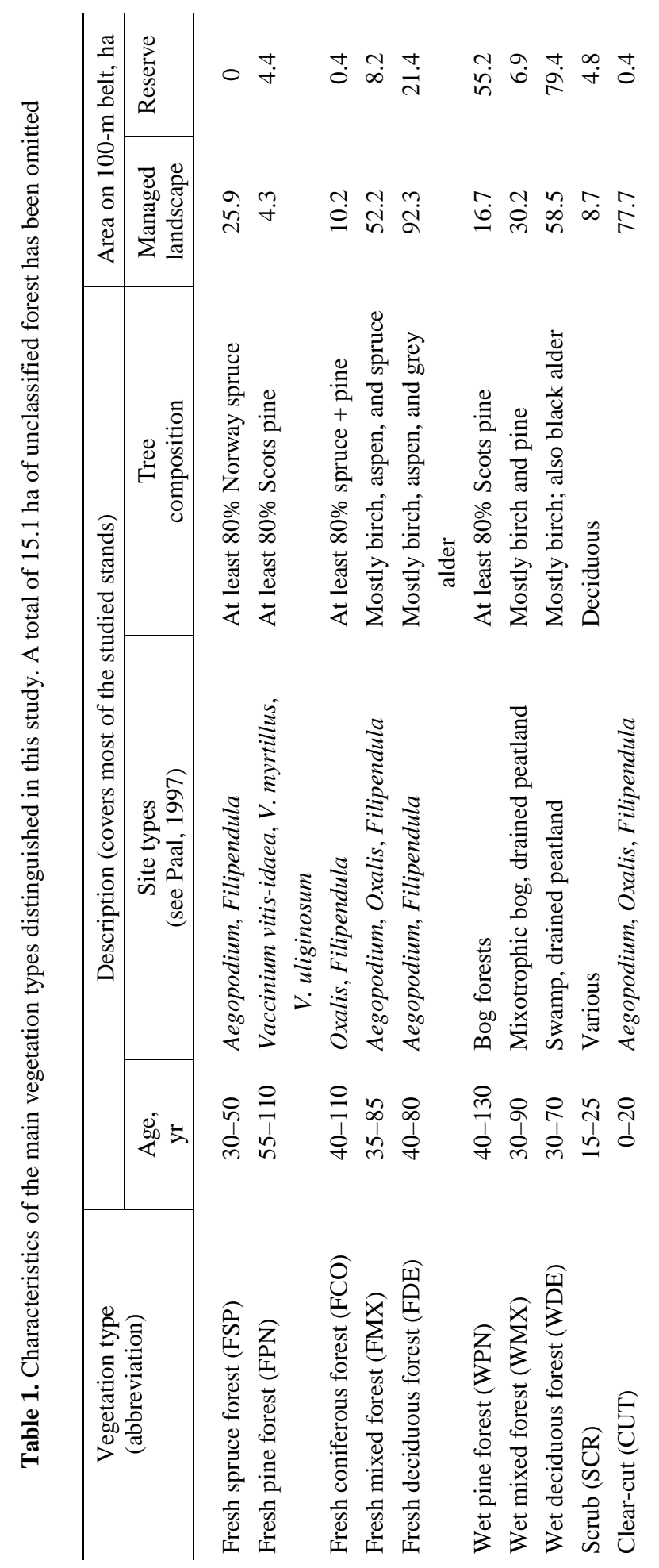


Distances are tracked from the map and counting paces. Density estimates are based on the main belt, where most pairs of those present can be observed (around 50-70\%; Tiainen et al., 1980; Hildén, 1981).

For the purposes of this study, two modifications were made to the original Finnish method (see Lõhmus, 2003a for details). First, since the counting unit was a pair, single non-territorially behaving (foraging, flushed, etc.) adult individuals of species with large home ranges (e.g. Strix uralensis, Dryocopos martius) or unstable pairs (e.g. Scolopax rusticola) were quantified as 0.5 pairs in their observation site. Similarly, territorial individuals of any species that moved freely in and back over belt borders during the observation were assigned as 0.5 pairs to the relevant belts. Secondly, instead of using all observations outside the conventional $25-\mathrm{m}$ main belt on both sides of the observer (hereafter: $50-\mathrm{m}$ belt), only those at 25-50 m distances ("peripheral belt") were additionally considered. This was done because habitat could not be determined for more distant birds and the averaged correction coefficients for distant observations may lead to results of unpredictable accuracy. Densities of most species were calculated from these 100 - $\mathrm{m}$ belts (main + peripheral belt), except in the least detectable species with less than $20 \%$ of pairs $>50 \mathrm{~m}$ away, which were treated only on the basis of the 50-m belt (Lõhmus, 2003a).

\section{Statistical analysis}

In most analyses, the sample unit was a transect. To explore differences between forest types or management treatments, all patches of the same type were pooled within a transect (as not fully independent observations). In the case of thinnings, I considered the area "thinned" if over $70 \%$ of the total area of the patches had been commercially thinned within the last 10 years, and "unthinned" if the thinned area formed no more than $20 \%$.

Conventional parametric (ANOVA, $t$-tests for independent and paired samples, linear regression) or (if the assumptions of parametric tests were not met) nonparametric statistics (Mann-Whitney $U$-test) was used for hypothesis testing. The diversity of bird fauna in different vegetation types was calculated according to the Shannon-Wiener index $\left(\mathrm{H}^{\prime}\right): \mathrm{H}^{\prime}=-\Sigma p_{i} \ln p_{i}$, where $p_{i}$ is the proportion of pairs of the $i$ th species among all bird pairs. Similarities of bird assemblages in thinned and unthinned forests of different types were identified with cluster analysis, based on Euclidean distances and Ward's method of linkage. The Statistica 6.0 software was used for computations.

To compare species richness between the landscapes, I regressed the species number against the log-transformed area by taking transects cumulatively in random order. The question how the managed landscape adds to species richness of the reserve was solved in the same way, by adding 10 random transects from the managed landscape to the 10 transects of the reserve. The regression coefficients were compared with $t$-tests. 


\section{RESULTS}

A total of 2786.5 pairs of birds of 72 species were recorded, including 64 species with 1424 pairs on counting belts (see Appendix). At the 20-ha (transect) scale, managed forest landscape had a denser and more species-rich bird fauna and as high abundance of species of conservation concern as the protected landscape (Table 2). However, the managed landscape had also higher small-scale diversity of vegetation types and larger areas of fresh forest (Table 2), which generally hosted a denser and more diverse bird fauna than wet forests did (Table 3).

Table 2. Mean characteristics of line transects in managed forests $(n=20)$ and the Alam-Pedja Nature Reserve $(n=10)$. Each transect covered approximately 20 ha (length $2 \mathrm{~km}$, width $100 \mathrm{~m}$ )

\begin{tabular}{l|c|c|c|c}
\hline \multirow{2}{*}{} & \multicolumn{2}{|c|}{ Mean $\pm 95 \%$ confidence interval } & \multicolumn{2}{c}{ Difference } \\
\cline { 2 - 5 } & Managed forest & Reserve & Statistic & $p$ \\
\hline Vegetation & & & & \\
No. of vegetation types & $5.2 \pm 1.4$ & $3.5 \pm 1.7$ & $t=2.8$ & 0.010 \\
Fresh forests, \% & $50.3 \pm 26.8$ & $20.7 \pm 29.8$ & $U=36.5$ & 0.007 \\
Clear-cuts, \% & $20.0 \pm 14.0$ & $0.2 \pm 0.4$ & $U=0$ & $<0.001$ \\
Birds & & & & \\
No. of species & $21.3 \pm 3.8$ & $15.2 \pm 6.2$ & $t=3.3$ & 0.003 \\
Density, pairs $/ \mathrm{km}^{2}$ & $327 \pm 91$ & $245 \pm 109$ & $t=2.2$ & 0.039 \\
SPEC, pairs $/ \mathrm{km}^{2}$ & $3.5 \pm 3.7$ & $3.5 \pm 5.4$ & $t=0.0$ & 1.0 \\
& & & &
\end{tabular}

SPEC - species of conservation concern (according to Eesti Ornitoloogiaühing, 2001).

Table 3. Density (pairs $/ \mathrm{km}^{2}$ ) and species richness (Shannon-Wiener index; $\mathrm{H}^{\prime}$ ) of the bird fauna of the main vegetation types in east-central Estonia. Total densities are based on summed areas of the vegetation types, whereas average values ( $\pm 95 \%$ confidence intervals) were calculated only for the most frequent types, having more than five transects with at least 3 ha of the particular vegetation type

\begin{tabular}{l|cc|c|c|c|c}
\hline \multicolumn{1}{c|}{ Vegetation type } & \multicolumn{3}{c|}{ For total area } & \multicolumn{3}{c}{ Average for transects } \\
\cline { 2 - 7 } & Density & $\begin{array}{c}\text { No. of } \\
\text { species }\end{array}$ & $\mathrm{H}^{\prime}$ & Density & $\mathrm{H}^{\prime}$ & $n$ \\
\hline Fresh spruce forest & 465 & 32 & 2.65 & & & \\
Fresh pine forest & 270 & 17 & 2.03 & & & \\
Fresh coniferous forest & 373 & 22 & 2.29 & & & \\
Fresh mixed forest & 486 & 45 & 2.71 & $448 \pm 112$ & $2.16 \pm 0.26$ & 7 \\
Fresh deciduous forest & 388 & 52 & 2.89 & $374 \pm 72$ & $2.11 \pm 0.15$ & 17 \\
Wet pine forest & 159 & 29 & 2.40 & $178 \pm 112$ & $1.47 \pm 0.24$ & 7 \\
Wet mixed forest & 301 & 31 & 2.70 & $310 \pm 133$ & $1.94 \pm 0.39$ & 6 \\
Wet deciduous forest & 302 & 47 & 2.55 & $293 \pm 59$ & $1.91 \pm 0.16$ & 13 \\
Scrub & 422 & 19 & 2.39 & & & \\
Clear-cut & 175 & 25 & 2.41 & $179 \pm 58$ & $1.50 \pm 0.28$ & 12 \\
\end{tabular}


To take the effects of vegetation type into account I analysed the most common forest types with two-way ANOVAs (Fig. 1). In that case avian species richness and density did not differ between the landscapes $\left(F_{1,39}=0.85, p=0.36\right.$ and $F_{1,39}=0.94, p=0.34$ for density and diversity, respectively).

Species-area plotting showed that at small (transect) scale both the managed and the protected landscape had fewer species than was the average for the vegetation types (compare the first points of both landscapes and the regression line in Fig. 2). In contrast, at larger scale, only the two most species-rich forest types (fresh mixed and deciduous forests) had a comparable number of species as the landscapes. Species richness of the managed forest and the reserve were similar at the landscape scale, both reaching 47 species on 10 transects (ca 200 ha; Fig. 2). The species-area relationships did not differ between the landscapes and the pooled data set from both landscapes (Table 4). In particular, the slope of the speciesarea function of the reserve was nearly identical with that of the pooled data set $(t=0.15, \mathrm{df}=28, p=0.91)$.

Compared with unthinned forests of the same type and age, bird assemblages in thinned forests had a similar density but a clear tendency towards lower species richness (in all five types; Table 5). The communities in thinned forests resembled each other or other forest types rather than the unthinned stands of their own type; particularly in the case of fresh spruce and mixed forests (Fig. 3).

(a)
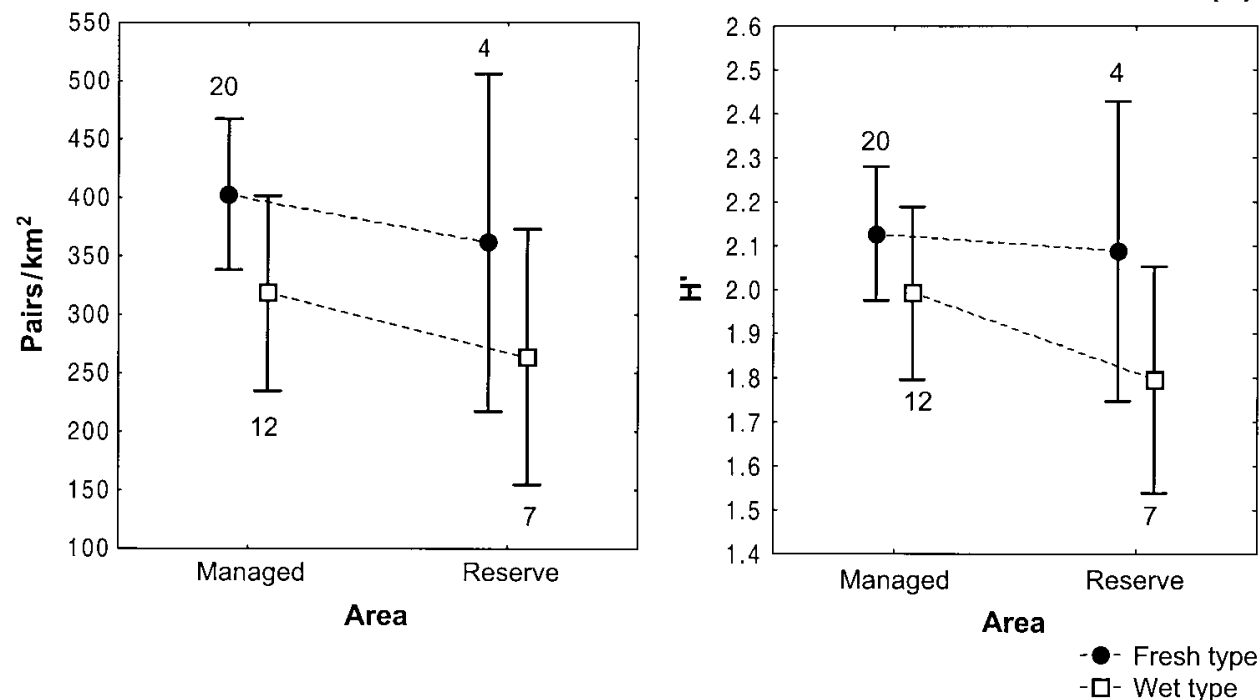

Fig. 1. Density (a) and diversity (Shannon-Wiener index $\mathrm{H}^{\prime}$; b) of the bird fauna of fresh and wet deciduous and mixed forests in the managed and protected landscape (mean $\pm 95 \%$ confidence intervals). Sample sizes are indicated with numbers on the graph. 


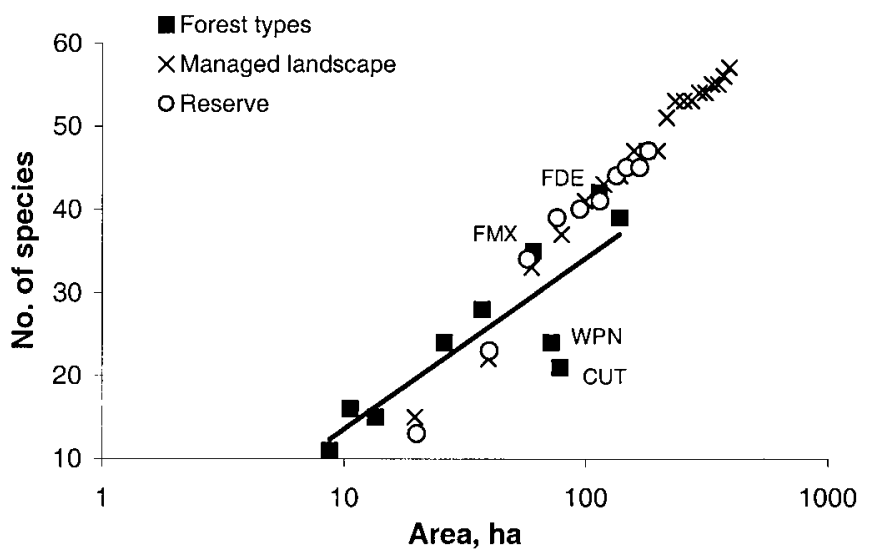

Fig. 2. Species-area relationships of forest birds in different vegetation types and in a managed and a protected landscape in east-central Estonia. Data are from 100-m belts of line transects, which for the two landscapes were considered in random order. The regression line is for vegetation types, and the most species-rich and species-poor types are indicated. Note the logarithmic scale of the $\mathrm{X}$-axis. See Table 1 for the abbreviations of vegetation types.

Table 4. Slopes and intercepts (mean \pm SE) of species-area regressions $(y=b \log (x)+a$, where $y=$ the total number species, $x=$ area (ha), and $a, b=$ constants) in the two landscapes and the pooled dataset of both landscapes. None of the slopes differed significantly ( $t$-tests, $p>0.1$ )

\begin{tabular}{l|c|c|c|c|c}
\hline \multirow{2}{*}{ Landscape } & \multicolumn{2}{|c|}{ Parameter estimates } & \multicolumn{2}{c|}{ Model fit } & \multirow{2}{*}{$\begin{array}{c}\text { Sample size, } \\
\text { transects }\end{array}$} \\
\cline { 2 - 5 } & $b$ & $a$ & $p$ & $R^{2}$ & 20 \\
\hline Managed & $32.4 \pm 1.1$ & $-25.9 \pm 2.4$ & $<0.001$ & 0.98 & 10 \\
Reserve & $35.1 \pm 2.5$ & $-30.9 \pm 4.9$ & $<0.001$ & 0.96 & 20 \\
Pooled & $35.5 \pm 1.7$ & $-33.4 \pm 3.9$ & $<0.001$ & 0.96 &
\end{tabular}

Table 5. Total density (pairs $/ \mathrm{km}^{2}$ ) and diversity (Shannon-Wiener index; $\mathrm{H}^{\prime}$ ) of birds in unthinned (A) and thinned (B) forests of five types in east-central Estonia. Total numbers (based on summed areas) are presented due to small and unequally distributed samples; the effects of thinning were tested between forest types (paired $t$-tests, $\mathrm{df}=4$ )

\begin{tabular}{l|c|c|c|c}
\hline \multirow{2}{*}{ Vegetation type } & \multicolumn{2}{c|}{ Density } & \multicolumn{2}{c}{ Diversity $\left(\mathrm{H}^{\prime}\right)$} \\
\cline { 2 - 5 } & $\mathrm{A}$ & $\mathrm{B}$ & $\mathrm{A}$ & $\mathrm{B}$ \\
\hline Fresh spruce forest & 409 & 447 & 2.34 & 2.17 \\
Fresh pine forest & 318 & 198 & 2.07 & 1.37 \\
Fresh mixed forest & 422 & 545 & 2.74 & 2.64 \\
Fresh deciduous forest & 439 & 300 & 2.82 & 2.68 \\
Wet deciduous forest & 279 & 283 & 2.53 & 2.27 \\
\hline Effect of thinning & \multicolumn{2}{c}{$t=0.38, p=0.72$} & \multicolumn{2}{c}{$t=2.47, p=0.069$}
\end{tabular}




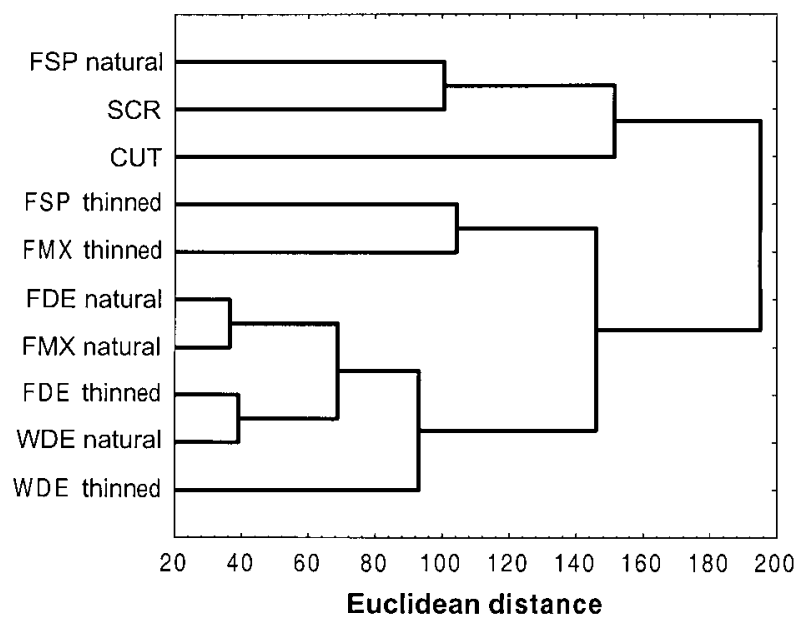

Fig. 3. Similarity of bird assemblages of thinned and unthinned forests of four types, clear-cuts, and scrub. The raw data included breeding densities of different species on 100-m belts. Ward's method was used for clustering. See Table 1 for the abbreviations of vegetation types.

\section{DISCUSSION}

The most important patterns revealed by my analysis were as follows. First, the managed landscape did not have lower densities or fewer species of breeding birds, and it was even more favourable for birds at the 20-ha scale than the reserve. Furthermore, the densities of species of conservation concern were as high in commercial forests as in the reserve (see Virkkala et al., 1994 for a rather different result in southern Finland). Hence, given that the species-area relationships of the two landscapes had similar slopes (Fig. 2) and commercial forests cover much larger areas than reserves, managed landscapes should currently host more bird species and generally larger populations of the species of conservation concern in Estonia than reserves.

Secondly, the major causes for the rich bird fauna in the managed landscape were obviously its productive forest types and more diverse vegetation (cf. Raivio \& Haila, 1990). It is well documented that (1) fresh mixed and deciduous forests, which were mostly confined to the managed area, have the highest density and species richness of birds in Estonia (Rootsi et al., 1988; Lilleleht, 1998), and (2) clear-cuts have very distinct bird assemblages (Fig. 3; cf. Głowaciński \& Järvinen, 1975), with species of open landscapes present. Yet, the clear-cuts of my sample included only three species (Saxicola rubetra, Acrocephalus palustris, Lanius collurio; see Appendix) that were not observed in forests as well, and all these species occur in good numbers on adjacent agricultural lands and/or open mires (Lõhmus et al., 1994 and unpublished data). 
Thirdly, given the generally rich bird fauna and different (and more productive) forest types of the managed landscape, one could expect that this area adds significantly to the species richness of the reserve. This was not the case. Instead, the similar slopes of the species-area curves of the reserve and the pooled sample of transects (Table 4) indicated that new species appeared due to a larger total area sampled, and not because of qualitative differences in the bird faunas. This apparent contradiction leads to two mutually non-exclusive explanations - either the specific species of fresh forest types of the managed landscape were not sampled (my relatively small samples missed rare species) or they were absent (due to local extinctions caused by forest management). Probably, both of these had their role in this study. On the one hand, less than two thirds of all (about 100; Lilleleht, 1998) Estonian forest bird species occurred at least once on my counting belts; notably many rare non-passerines were absent. On the other hand, (1) the managed area was more representatively sampled (more transects, larger region) than the reserve, not vice versa; (2) case studies on some rare species (Strix uralensis, Dendrocopos leucotos, Picoides tridactylus) have revealed significantly reduced densities in the managed landscapes of the study area (Lõhmus et al., 2000; Lõhmus, 2003b), and (3) studies on old-growth forests of fresh types in Estonia (Randla, 1963, 1965; Rootsmäe \& Rootsmäe, 1993) have shown their very dense and diverse bird fauna compared with that documented by me.

Impoverishment of bird fauna by forestry was further supported by the analysis of thinnings. While these did not influence the total density of breeding birds (a similar result - Artman, 2003), several authors have noticed that different species benefit from partially cut and unmanaged forests (King \& DeGraaf, 2000; Bull \& Wales, 2001; Artman, 2003; but see Easton \& Martin, 1998 for no effect in young plantations). Indeed, my analysis demonstrated that bird assemblages changed after thinning, so that they even resembled more some other forest types than unthinned stands of their original type. The shifts (Fig. 3) suggest that the main factor was openness of the stand, since, for example, fresh deciduous forests resembled the more open wet deciduous sites after thinning, and the middle-aged fresh spruce forests were closest to scrub before thinning but very different afterwards. This effect of thinning, together with the clear tendency towards reduced local species richness, may be negative for preserving the specific biota of unmanaged forests of fresh types. This does not mean that special forms of thinning can not be used for old growth restoration, but such techniques deviate significantly from the ordinary commercial thinnings (e.g. Carey et al., 1999).

Given the local diversity-reducing effect of thinnings, one should expect that within a forest type, local bird diversities should be higher in the reserve (where there is no timber harvesting). Figure $1 b$ does not support this. Hence, there could be additional diversity-creating processes that counterbalance the negative influences of thinnings. For example, the landscape context around managed forests (mostly productive agricultural lands) may give additional species compared with the nutrient-poor mires surrounding the forests of the Alam-Pedja Nature Reserve (see, e.g., Sisk et al., 1997 and Howell et al., 2000, about such landscape effects on 
forest birds). However, the similarity of species-area curves did not support the idea of distinct species pools (see above) and I consider a more likely reason the higher density of edges between different vegetation types (cf. Table 2), which may create relatively more species-rich local aggregations in the managed than the protected landscape.

Considering the evidence and reasoning above, I conclude that the bird fauna of managed forest landscapes is still species-rich and has high value for conservation, including the establishment of reserves in Estonia. Compared with its natural state, however, the bird fauna is likely to be impoverished and continues to lose its specific species also nowadays. Therefore, using the existing middle-aged or old unmanaged second-growth for new forest reserves (as proposed in Lõhmus, 2002) seems to be an acceptable strategy if the potential sites of conservation are immediately excluded from commercial use. Later, also opportunities to restore the structural features of natural forests in these areas should be studied to create old-growth like habitats in a reasonable time (cf. Hanski, 2000).

\section{ACKNOWLEDGEMENTS}

I am extremely grateful to Jaanus Remm for the preparatory work of this study - outlining the transects, marking them in the field, preparing the maps for fieldwork, and helping to digitalize transect and habitat borders. The study was financed by the Estonian Science Foundation (grant No. 5257).

\section{REFERENCES}

Andersson, L., Martverk, R., Külvik, M., Palo, A. \& Varblane, A. 2003. Woodland Key Habitat Inventory in Estonia 1999-2002. Regio AS, Tartu.

Angelstam, P. \& Andersson, L. 2001. Estimates of the needs for forest reserves in Sweden. Scan. J. For. Res., Suppl., 3, 38-51.

Angelstam, P., Roberge, J.-M., Lõhmus, A., Bergmanis, M., Brazaitis, G., Breuss, M., Edenius, L., Kosinski, Z., Kurlavičius, P., Larmanis, V., Lukens, M., Mikusinski, G., Priednieks, J., Račinskis, E. \& Stradzs, M. 2004. Habitat suitability modelling and focal species - a review of habitat parameters for forest birds in the Baltic Sea region. Ecol. Bull., 51, in press.

Artman, V. L. 2003. Effects of commercial thinning on breeding bird populations in western hemlock forests. Am. Midl. Nat., 149, 225-232.

Bull, E. L. \& Wales, B. C. 2001. Effects of disturbance on birds of conservation concern in eastern Oregon and Washington. Northwest Sci., 75 Suppl., 166-173.

Carey, A. B., Thysell, D. R. \& Brodie, A. W. 1999. The forest ecosystem study: background, rationale, implementation, baseline conditions, and silvicultural assessment. USDA For. Serv. Gen. Tech. Rep., PNW-GTR-457.

Easton, W. E. \& Martin, K. 1998. The effect of vegetation management on breeding bird communities in British Columbia. Ecol. Appl., 8, 1092-1103.

Eesti Ornitoloogiaühing. 2001. Bird species of conservation concern in Estonia. Hirundo Suppl., 4, 2-4.

Ellermaa, M. 2003. Finnish line transect method. Hirundo, 16, 35-49. 
Głowaciński, Z. \& Järvinen, O. 1975. Rate of secondary succession in forest bird communities. Ornis Scand., 6, 33-40.

Hanski, I. 2000. Extinction debt and species credit in boreal forests: modelling the consequences of different approaches to biodiversity conservation. Ann. Zool. Fenn., 37, 271-280.

Hildén, O. 1981. Sources of error involved in the Finnish line-transect method. Stud. Avian Biol., 6, 152-159.

Howell, C. A., Latta, S. C., Donovan, T. M., Porneluzi, P. A., Parks, G. R. \& Faaborg, J. 2000. Landscape effects mediate breeding bird abundance in midwestern forests. Landscape Ecol., 15, 547-562.

Järvinen, O., Koskimies, P. \& Väisänen, R. A. 1991. Land transect census of breeding land birds. In Monitoring Bird Populations (Koskimies, P. \& Väisänen, R. A., eds.), pp. 33-40. Zoological Museum, Finnish Museum of Natural History.

King, D. I. \& DeGraaf, R. M. 2000. Bird species diversity and nesting success in mature, clearcut and shelterwood forest in northern New Hampshire, USA. For. Ecol. Manage., 129, 227-235.

Lilleleht, V. 1998. Estonian bird fauna, diversity and changes in different habitats. In Eesti looduse mitmekesisus ja selle kaitse (Lilleleht, V., ed.), pp. 87-104. Teaduste Akadeemia Kirjastus, Tartu-Tallinn.

Lõhmus, A. 2002. The lack of old-growth forest - a threat to Estonian biodiversity. Proc. Estonian Acad. Sci. Biol. Ecol., 51, 138-144.

Lõhmus, A. 2003a. The Finnish method of line transects in the light of forest bird censuses in eastcentral Estonia. Hirundo, 16, 91-102.

Lõhmus, A. 2003b. Do Ural Owls suffer from the lack of nest sites in managed forests? Biol. Conserv., 110, 1-9.

Lõhmus, A., Ader, A., Rander, R. \& Tammur, E. 1994. On the bird fauna of Laeva-Palupõhja. Hirundo Suppl., 1, 3-36.

Lõhmus, A., Elts, J., Evestus, T., Kinks, R., Kulpsoo, L., Leivits, A., Nellis, R. \& Väli, Ü. 2000. Numbers of breeding woodpeckers in Estonia. Hirundo, 13, 67-81.

Lõhmus, A., Kohv, K., Palo, A. \& Viilma, K. 2004. Loss of old-growth, and the minimum need for strictly protected forests in Estonia. Ecol. Bull., 51, in press.

Oksanen, L. 2001. Logic of experiments in ecology: is pseudoreplication a pseudoissue? Oikos, 94, 27-38.

Paal, J. 1997. Eesti taimkatte kasvukohatü̈̈pide klassifikatsioon. Keskkonnaministeeriumi Info- ja Tehnokeskus, Tallinn.

Parmasto, E. 2002. Järvselja kaitsealuse põlismetsa seenestiku kui võrdlusetaloni analüüs. Institute of Environmental Protection, Tartu (unpublished report).

Raivio, S. \& Haila, Y. 1990. Bird assemblages in silvicultural habitat mosaics in southern Finland during the breeding season. Ornis Fenn., 67, 73-83.

Randla, T. 1963. Preliminary data on bird population density in the spruce groves at Neeruti. Loodusuurijate Seltsi aastaraamat, 55, 181-194.

Randla, T. 1965. Die Nistvogelfauna des Hainwaldes am Flusse des Glintes von Saka-Ontika-Toila. Loodusuurijate Seltsi aastaraamat, 57, 162-171.

Rootsi, I., Viht, E. \& Õun, A. 1988. Land bird associations of Lahemaa National Park. Lahemaa Uurimused, 3, 143-157.

Rootsmäe, I. \& Rootsmäe, L. 1993. The ornithofauna of the Järvselja Forest Reserve. Loodusuurijate Seltsi aastaraamat, 74, 334-341.

Sisk, T. D., Haddad, N. M. \& Ehrlich, P. R. 1997. Bird assemblages in patchy woodlands: modeling the effects of edge and matrix habitats. Ecol. Appl., 7, 1170-1180.

Stokland, J. N. 1997. Representativeness and efficiency of bird and insect conservation in Norwegian boreal forest reserves. Conserv. Biol., 11, 101-111.

Thompson, I. D., Baker, J. A. \& Ter-Mikaelian, M. 2003. A review of the long-term effects of postharvest silviculture on vertebrate wildlife, and predictive models, with an emphasis on boreal forests in Ontario, Canada. For. Ecol. Manage., 177, 441-469. 
Tiainen, J., Martin, J.-L., Pakkala, T., Piironen, J., Solonen, T., Vickholm, M. \& Virolainen, E. 1980. Efficiency of the line transect and point count methods in a South Finnish forest area. In Bird Census Work and Nature Conservation (Oelke, H., ed.), pp. 107-113. Dacherverband Deutscher Avifaunisten, Göttingen.

Trass, H. 1997. Characteristics used for identifying primeval forests in Estonia. In Problems of Contemporary Ecology (Frey, T., ed.), pp. 235-239. Tartu.

Trass, H., Vellak, K. \& Ingerpuu, N. 1999. Floristical and ecological properties for identifying of primeval forests in Estonia. Ann. Bot. Fenn., 36, 67-80.

Vellak, K. \& Paal, J. 1999. Diversity of bryophyte vegetation in some forest types in Estonia: a comparison of old unmanaged and managed forests. Biodiv. Conserv., 8, 1595-1620.

Virkkala, R. 1996. Metsien suojelualueverkon rakenne ja kehittämistarpeet - ekologinen lähestymistapa. Suomen Ympäristö 16, Helsinki.

Virkkala, R., Rajasärkkä, A., Väisänen, R. A., Vickholm, M. \& Virolainen, E. 1994. Conservation value of nature reserves: do hole-nesting birds prefer protected forests in southern Finland? Ann. Zool. Fenn., 31, 173-186.

\title{
Haudelinnukooslused kahes Eesti metsamaastikus: kas majandusmetsadel on väärtust bioloogilise mitmekesisuse kaitse jaoks?
}

\begin{abstract}
Asko Lõhmus
Eesti praegused metsakaitsealad ei ole bioloogilise mitmekesisuse säilimiseks piisavalt suured ega esinduslikud, mistõttu tuleb hinnata ka seni kaitsmata metsade looduskaitseväärtust. Töös võrreldakse transektloenduste andmetel AlamPedja looduskaitseala ja seda ümbritsevate metsade haudelinnustikku. Väikeses mastaabis (20 ha) oli majandusmetsade linnustik kaitseala omast tihedam ja liigirikkam; looduskaitseliselt oluliste liikide arvukus ei erinenud. See tulenes viljakate metsade valdamisest ja taimkatte suuremast mitmekesisusest väljaspool kaitseala, sest maastiku mastaabis oli alade liigirikkus sarnane. Liigirikkus kasvas pindala suurenedes ühtmoodi kaitsealal ning juhul, kui majandusmetsade andmestik oli kaitseala omale liidetud. See näitab, et liikide arv suurenes üksnes pindala kasvu tõttu ning majandusmetsa linnukooslus ei täiendanud kaitseala oma kvalitatiivselt. Seda võinuks eeldada metsatüüpide erinevuse põhjal. Harvendusraied ei mõjutanud lindude asustustihedust, kuid muutsid linnustiku koosseisu ning kaldusid vähendama liigirikkust. Järeldati, et majandusmetsadel on Eestis endiselt ka looduskaitselist väärtust, kuigi majandamine on nende algset liigirikkust kahandanud. Raietest puutumatutena püsinud keskealiste või vanade puistute kasutamine uute kaitsealade piiritlemiseks näib olevat arvestatav looduskaitsestrateegia, kui need potentsiaalsed kaitsealad jäetakse planeeritud majandustegevusest kohe välja.
\end{abstract}




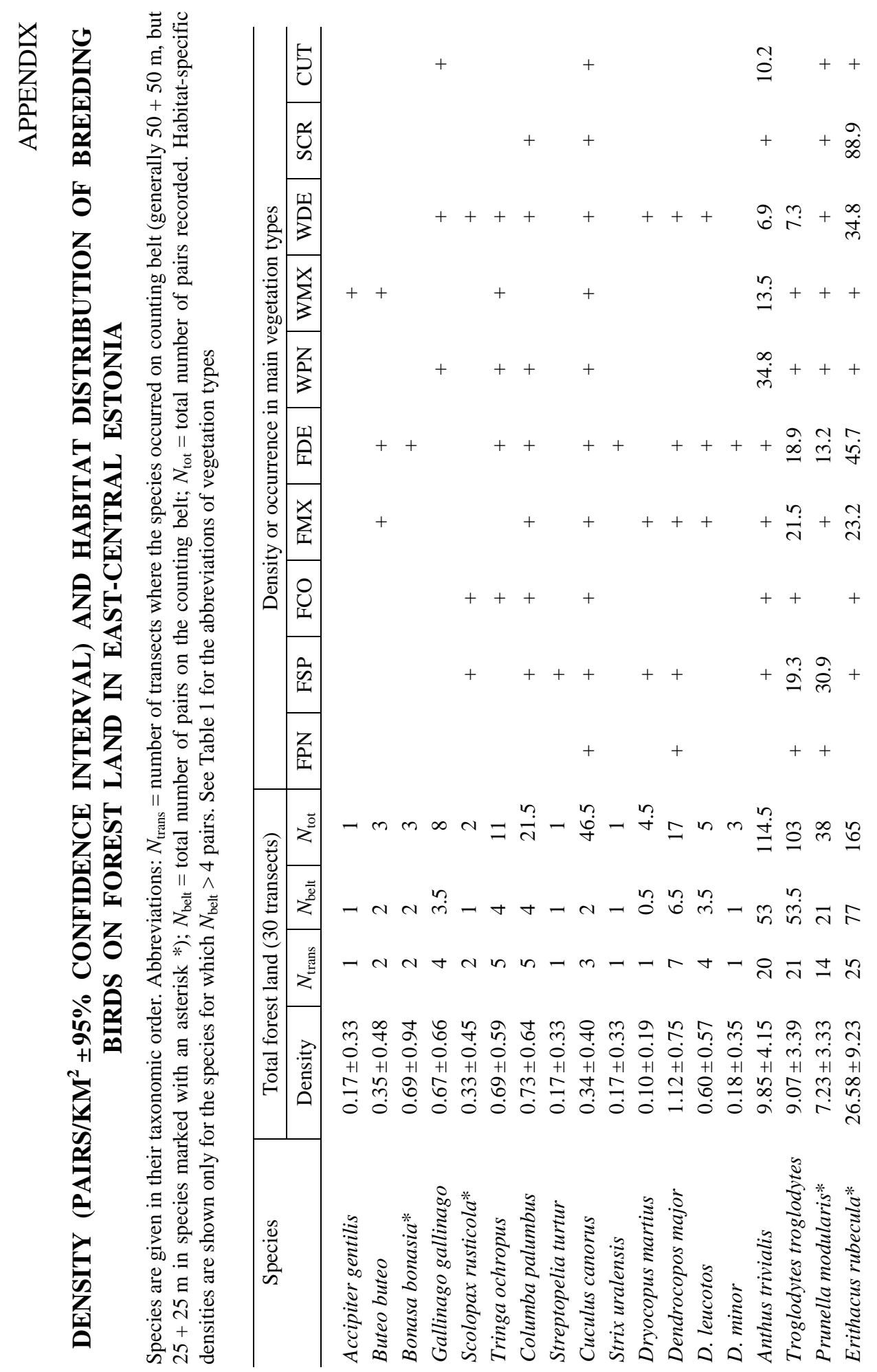




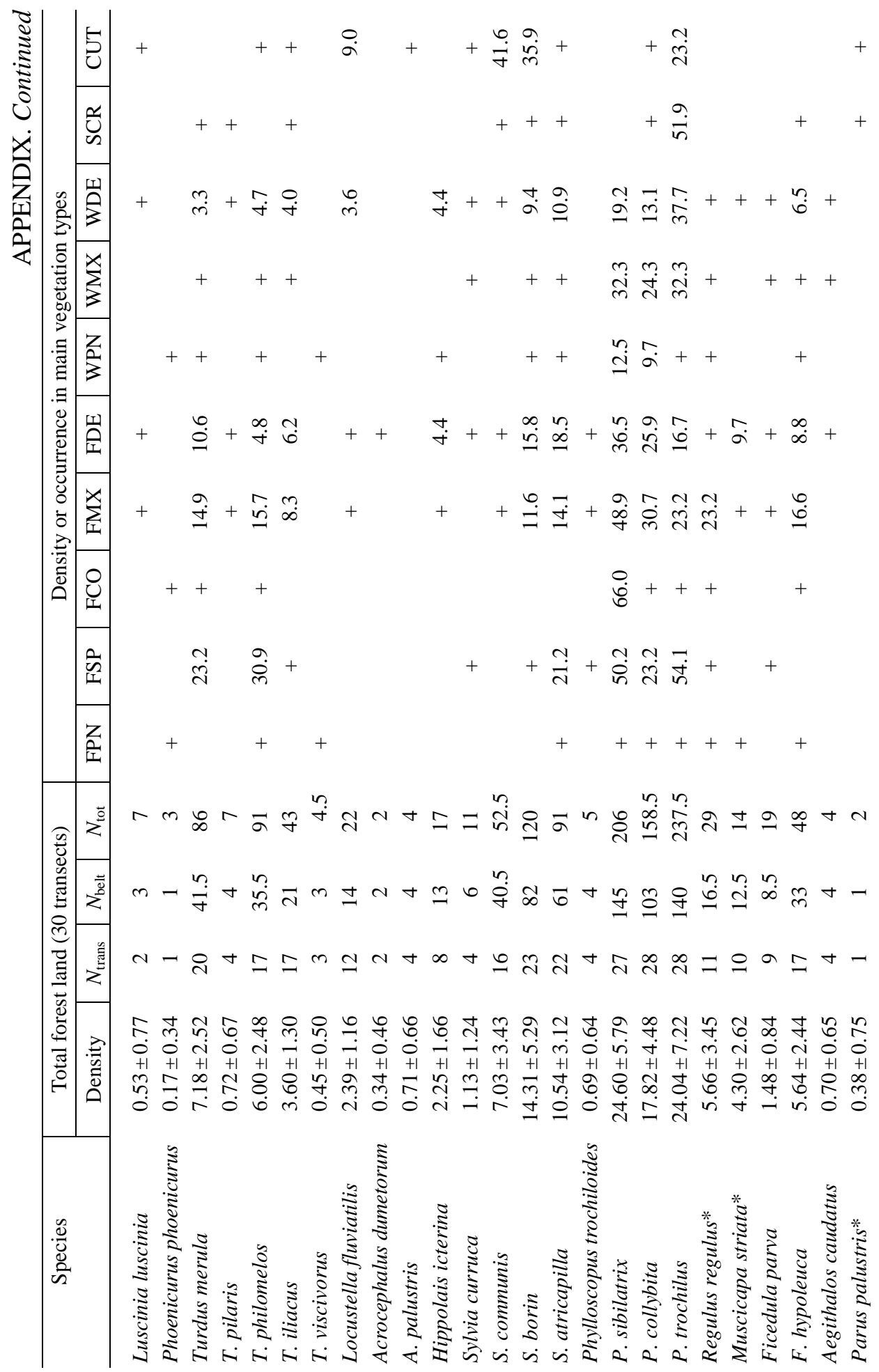




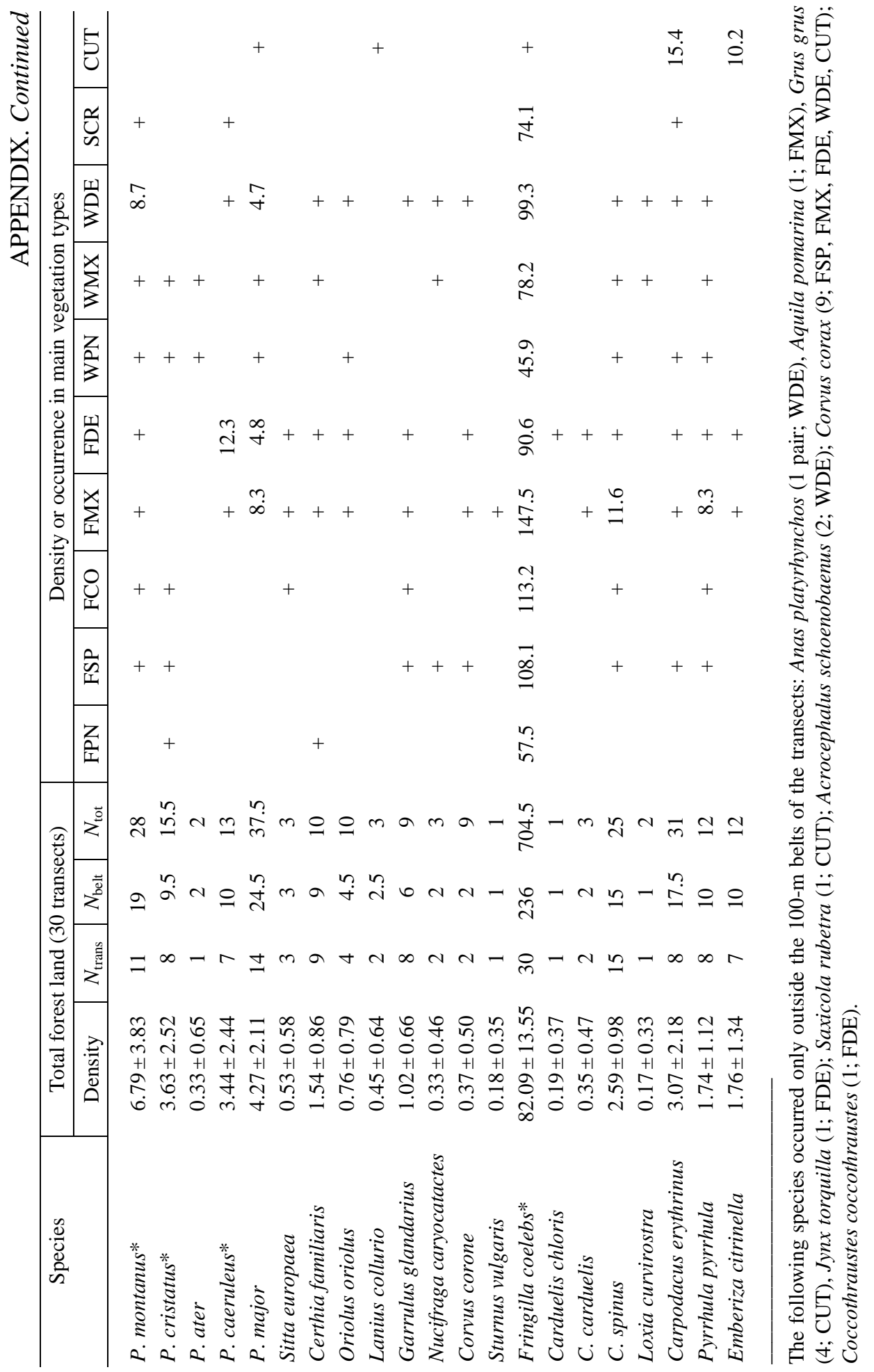

